Research Article

\title{
Prevention of Inhalant Abuse Behaviour in Middle High School Students in South Sulawesi 2019
}

Uswatun Khasanah ${ }^{1 *}$, Muhammad Syafar ${ }^{1}$ and Darmawansyah ${ }^{2}$

${ }^{1}$ Departement Promotion of public health, Faculty of Public Health

${ }^{2}$ Department the health policy administration, Faculty of Public Health

*Corresponding Author

Uswatun Khasanah

\begin{abstract}
Inhalation abuse refers to the inhalation of volatile substances for euphoric effects. Inhalation abuse behavior has become a significant public health problem in many developed and developing countries. This research was conducted in South Sulawesi. The type of research used in this study is qualitative with the phenomenology approach. Informants in this study were selected by Purposive Sampling. The data collection method used in this study is in-depth interviews. Data collection techniques used was in-depth interviews and then the data were analyzed using content analysis methods. In this study, the researchers tested the validity of the data using the triangulation approach. The result is that all the motivating informants, namely parents, police, and counseling teachers have a role in preventing deviant behavior from inhaling glue by students. Providing material about drugs by health workers and the police is one form of prevention. In addition, educators provide counseling to students who behave deviant. Parents provide supervision to students so they are not wrong in choosing friends to hang out and tell them to do positive things.

Keywords: Prevention, Deviant Behavior, Inhalan abuse, Students.
\end{abstract}

\section{INTRODUCTION}

The behavior of glue abuse (Ngelem) behavior has become a significant public health problem in many developed and developing countries. Abuse of glue is a common form of Narcotics, Psychotropic, and other Addictive Substances (NAPZA) abuse with volatile substances and is usually followed by deliberate inhalation of vapors to get drunk (Brenesel et al., 2016). Glue has been misused as an inhaler for decades and is known as "inhaling glue or glue" which is inherent in habits (Jayanth et al., 2017). Inhalan is an addictive substance that is classified as drug in the form of ingredients or substances or drugs that when it enters the human body can affect the body especially the brain or central nervous system. This can cause physical, psychological and social health problems due to habits, addiction (addiction) and dependence (dependencies) (Husna et al., 2016).

Toluene is the main toxic agent involved when inhaling glue and is most misused. The results show that toluene-based products are the main substances inhaled in Mexico and internationally (Yurtseven et al., 2018). In addition, glue abuse often starts at an early age, in almost half of cases before age 13 and in more than $80 \%$ of users before the age of 15 years. Similar studies show that rates of inhalant use peaked during mid-year adolescence, with rates of use between 14 years $(3.4 \%)$ becoming almost twice that of 12 years (1.8\%) (Koposov et al., 2018).

Attention needs to be given to the authorities regarding the health hazards of breathing glue to deal with this bad behavior. Thus, behavioral mediation or preventive measures to reduce the behavior of sucking adolescent glue as the nation's successor does not end in the stage of dependence. Therefore, precautionary measures through a strict pattern of care and religiosity and having friends who are not users can minimize access of adolescents to obtain and actively use these substances so that they become a factor to prevent glue abuse and / or help adolescents stop behaving ngelem (Strock et al., 2016).

In addition, as for the form of prevention carried out by the school based on Rafika's 2016 research results, which are preventive forms of control in the form of advice and advice until refresive controls

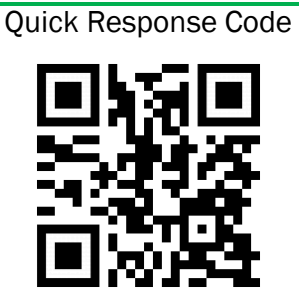

Journal homepage: http://www.easpublisher.com/easjehl/

Article History

Received: 25.06.2018

Accepted: 14.06.2019

Published: 27.07.2019
Copyright @ 2019: This is an open-access article distributed under the terms of the Creative Commons Attribution license which permits unrestricted use, distribution, and reproduction in any medium for non commercial use (NonCommercial, or CC-BY $\mathrm{NC}$ ) provided the original author and source are credited. 
are carried out if there are students who look depressed and there are indications that doing things done by schools is of course limited counseling guidance.

The preventive effort that has been carried out by the Makassar Polrestabes is by working with the Makassar City National Narcotics Agency to provide education or enlightenment by holding information on the dangers of drugs and addictive substances in several schools in the city of Makassar as well as monitoring and understanding how protecting children with religion and education, in line with its vision and mission of creating a good young generation through empowering human resources can be improved again (Achmad et al., 2017).

The description above explains that the behavior of glue abuse (ngelem) is one of the serious problems that have a negative impact on health and cause social problems, especially those at risk, namely teenagers among middle school students. So the importance of prevention efforts is carried out by the environment around students to help in directing behavior to better.

\section{METHODOLOGY \\ Design of Research}

The type of research used in this study is qualitative with a phenomenological approach. This research was conducted in South Sulawesi.

\section{Population and Samples}

Informants in this study were selected by Purposive Sampling. The informants in this study were: Middle school students, parents, counseling teachers, and the Police.

\section{Data Collection}

Data collection is done by extracting data from various data sources to clarify information in the field. The data obtained is primary data. This primary data is obtained by observation and in-depth interviews. Before in-depth interviews, researchers conducted observations at the research location to find informants who were in accordance with predetermined characteristics.

\section{Data Analysis}

Data analysis in this study was carried out interactively and continued continuously to complete so that the data was saturated. Analysis of the data used in this study is the analysis of content or content, namely how to find written or visual material meaning by means of systematic content allocation to detailed categories by dividing data into small parts then coding in each section then collecting coding in similar groups and calculated (Martha et al., 2016)

\section{RESULTS AND DISCUSSION}

South Sulawesi Province is divided into 24 regencies / cities. Where this research is located in Gowa Regency, South Sulawesi Province in 2019. Table 1.1 is the characteristic of informants as a driving factor, namely parents' informants of students who behave deviant or do not behave deviantly, the police and junior high school counseling teachers.

Table. 1.1. Characteristics of Informants Enabling Factors

\begin{tabular}{|c|c|c|c|c|c|}
\hline No & Name & gender & Age & Job & Etc. \\
\hline 1 & SW & Female & 41 years old & House Wife & Parents of Students who do not behave deviantly \\
\hline 2 & NB & Female & 38 years old & House Wife & Parents of Students who do not behave deviantly \\
\hline 3 & JM & Female & 40 years old & House Wife & Parents of Students who do behave deviantly \\
\hline 4 & YL & Female & 43 years old & House Wife & Parents of Students who do behave deviantly \\
\hline 5 & IC & Female & 40 years old & Teacher & Counseling Teacher \\
\hline 6 & IN & Female & 38 years old & Teacher & Counseling Teacher \\
\hline 7 & KR & Female & 41 years old & Teacher & Counseling Teacher \\
\hline 8 & AH & Male & 37 years old & Police & Police \\
\hline \multicolumn{7}{|c|}{ Source: primary data and secondary data, March - April 2019 }
\end{tabular}

\section{Prevention of Infrastructure Abuse by Enabling Factors (Parents, Teachers of Country Counseling and Police)}

Notoatmodjo's theory (2014) defines that a person's attitude is easily influenced to respond to environmental stimuli, which can initiate or guide the person's behavior. Attitudes also contain the notion of being a tendency to react positively (favorably) or negatively (unfavorably) to certain people, objects or situations. Therefore, attitudes or actions taken by parents, the police and counseling tutors in schools have a very important role to play in preventing students from abuse of substance.

\section{Prevention by Parents of Student}

Based on the results of the study, all the informants of the motivating factors stated that they did not like the behavior of inhalant abuse because it was a bad behavior because it could damage children's health. In the study of Whitesell, M. et al.,. (2013) stated that adolescents are very vulnerable to involvement in substance abuse because of their underdeveloped brain condition, which can lead to a lack of decision-making abilities and increased long-term effects of substance abuse including glue. Alhyas, L. et al., (2015), many factors increase the risk of substance abuse in 
adolescents such as peer pressure, insufficient knowledge of the harmful consequences, family-related factors, affordability and availability.

The form of preventive handling carried out by various informants of driving factors has different ways. Such as the form of prevention of parents' informants to their children so that they do not slip, namely by not giving their children permission to leave late at night, advising them to improve their prayers, limiting their snacks, monitoring children's activities, and advising them to associate with good people so that they do not deviate.

However, the lack of attention given by parents can motivate the behavior of children. Therefore, the family has an important role in changing a child's behavior. Lestari (2016) states that family is an important place for child development physically, emotionally, spiritually, and socially, where the family is the first social environment of a child that will be formed and influenced by the attitudes and actions of their parents.

Mclaughlin et al., (2016) shows that the relationship between parents and children can protect adolescents from drug use. Care interventions to prevent or reduce juvenile drug use must contain a component of parent-child bonding, educating parents about the importance of quality time with their children, to offset the potential negative impact of peer groups. This may be very important because children will grow older and spend more time studying alone. Taking the time to eat with family can provide an opportunity for discussion. For example, related to how they care (adapting the parenting style based on the child's temperament or the placement of children among siblings). Family-based interventions can also contain effective communication components such as talking, listening and relating to children and the importance of sharing information or feelings.

\section{Prevention by Counseling Guidance Teachers in Junior High School Students}

A positive and healthy atmosphere at home along with a supportive care environment in school is the most important thing in supporting efforts to prevent deviant behaviors in students (Jesuraj, 2012). Based on the results of the study, an educator (teacher) will do gradual counseling to students to take the drop out action if students are still doing ngelem behavior.

Coward (2018), one of the priorities of a teacher is to provide time and space for students to discuss their personal problems related to parents, peers, academics, and physical and psychological problems that allow for the release of emotional effects that cause students to behave deviate. In this study prevention efforts in the form of counseling have been given by teachers in schools to students with several stages such as classical guidance, group guidance, to individual guidance.

In addition, prevention of other deviant behaviors provided by the school can be through extracurricular activities. A study conducted on 2903 Polish teenagers aged 13 and 14 years, adolescent participation in sports, religious and artistic activities will protect them against alcohol consumption (Habib et $a l$. , 2014). This protection stems from the fact that extracurricular activities fill students' free time and allow them to learn social roles and develop skills that contribute to the positive development of students.

\section{Prevention by the police}

Meanwhile, the police have their own ways to deal with deviant behavior. The police will further investigate the behavior of children, if it is at an acute stage of dependence, the police will advise parents to rehabilitate their children. Educators and police officers have similarities in preventing inhalation abuse by providing counseling to students with drug-related material. Because, drug dependence is a chronic disorder; many have stopped and relapsed again, stopped again and relapsed again, and so on. Many good and beneficial functions of life are disrupted by drugs and not a few people give up because they are unable to escape from drugs (Hakim, 2004).

According to the Theory of Planned Behavior, intention is formed consciously and it reflects how strong a person's willingness to do certain behaviors. Intentions are considered motivations that influence behavior (Yarnell et al., 2012). The results of this study indicate that peers play a significant role in influencing students' prevention efforts towards ngelem behavior. In this case, the motivation of students to avoid behaviors encourages them to carry out positive activities such as taking extracurricular activities, tutoring or even just playing games. Thus, peers act as initiating agents to motivate students to prevent ngelem behavior.

Based on the above, there is no single step that will be effective in preventing inhalation abuse. However, it is necessary to involve all relevant stakeholders to jointly overcome the problem of inhalation abuse (deviant deviant behavior) from a different perspective. Based on the above, there is no single step that will be effective in preventing inhalation abuse. However, it is necessary to involve all relevant stakeholders to jointly overcome the problem of inhalation abuse (deviant deviant behavior) from a different perspective.

\section{CONCLUSION}

All motivating informants on the misuse of inhalants by students have their own way of taking preventive measures. Parents pay more attention to child supervision. Educators provide counseling to students to provide gradual counseling. Likewise with 
the police who routinely conduct counseling to drugrelated schools. The things that need to be done is the school makes a program that can involve parents in monitoring students. In addition, the need for peer group programs in schools is activated to make students better aware of deviant behavior more broadly.

\section{REFERENCES}

1. Achmad, et at. (2017). Fenomena "Ngelem" Oleh Anak Jalanan Di Kota Makassar. Jurnal Penelitian \& PPM ISSN: 2442-448X Vol 4, No: 2 Hal: 129 389

2. Alhyas, L., Al Ozaibi, N., Elarabi, H., El-Kashef, A., Wanigaratne, S., Almarzouqi, A., ... \& Al Ghaferi, H. (2015). Adolescents' Perception Of Substance Use And Factors Influencing Its Use: A Qualitative Study In Abu Dhabi. Jrsm Open, 6(2)

3. Brenesel D.M., Goran S., \& Vladimir P. (2016). Fatal intoxication with toluene due to inhalation of glue. Journal of forensic sciences, 61(3), 875-878.

4. Coward, I. G. (2018). Adolescent Stress: Causes, Consequences, and Communication as an Interventional Model. Canadian Journal of Family and Youth/Le Journal Canadien de Famille et de la Jeunesse, 10(1), 25-51.

5. Jayanth, S.H., Hugar B.S., Praveen S., \& Girish Chandra Y.P. (2017). Glue sniffing. Medico-Legal Journal, 85(1), 38-42.

6. Martha E. \& Kresno S. (2016). Metodologi Penelitian Kualitatif untuk Bindang Kesehatan. Jakarta: PT Rajawali Pers.

7. Rafika. (2016). Lemahnya Kontrol Sosial Pada Masyarakat Pedesaan (Studi Kasus Anak-Anak dan Remaja Kecanduan Menghisap Lem Aibon di Desa Suka Negeri, Kecamatan Topos-Kabupaten Lebong. Fokus: Jurnal Kajian Keislaman dan Kemasyarakatan, 1(01):16-24

8. Habib, E. L., Zimmerman, M. A., \& Ostaszewski, K. (2014). International note: Prevailing with extracurricular activities in an alcohol-dominated environment: Sex differences in resilience among middle school youth. Journal of adolescence, 37(6), 901-904.

9. Hakim, M. Arief. (2004). Bahaya Narkoba dan Alkohol. Bandung: Komp. Cijambe Indah

10. Husna, et al.,. (2017). "Hubungan Pengetahuan, Teman Sebaya dan Status Ekonomi dengan Perilaku Ngelem pada Anak Jalanan di Kota Kendari Tahun 2016." Jurnal Ilmiah Mahasiswa Kesehatan Masyarakat 1.3

11. Koposov, R, et al.,. (2018). Inhalant use in adolescents in northern Russia. Social psychiatry and psychiatric epidemiology, 53(7), 709-716.

12. Storck, M., Black, L., \& Liddell, M. (2016). Inhalant Abuse and Dextromethorphan. Child and Adolescent Psychiatric Clinics, 25(3), 497-508.

13. Notoatmodjo, S. (2014). Promosi Kesehatan dan Ilmu Perilaku. Jakarta: Rineka Cipta.

14. McLaughlin, A., Campbell, A., \& McColgan, M. (2016). Adolescent substance use in the context of the family: A qualitative study of young people's views on parent-child attachments, parenting style and parental substance use. Substance use \& misuse, 51(14), 1846-1855.

15. Lestari, S. (2016). Psikologi Keluarga: Peneneman Nilai Dan Penanganan Konflik Dalam Keluarga. Jakarta: Prenadamedia Group

16. Jesuraj, M. J. (2012). Impact of substance abuse on families. Rajagiri Journal of Social Development, 4(2), 18-23.

17. Whitesell M ,. Annette B. Jennifer P., And Mark B. (2013). Familial, Social, and Individual FactorsContributing to Risk for Adolescent Substance Use. Hindawi Publishing Corporation Journal of Addiction. Volume 2013, Article Id 579310,9 . 